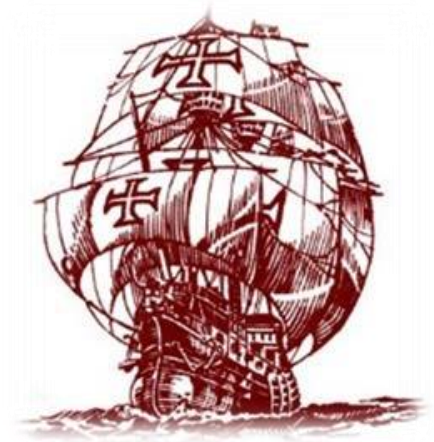

\author{
Nau Literária: crítica e teoria de literaturas \\ www.seer.ufrgs.br/nauliteraria \\ ISSN 1981-4526 - PPG-LET-UFRGS - Porto Alegre \\ Vol. 11 N. 02 \\ Literatura e Guerra
}

\title{
DE TRAUMAS A NOTAS DE RODAPÉ: UMA LEITURA PRELIMINAR DE NOTAS SOBRE GAZA, DE JOE SACCO
}

\author{
JULIANE VARGAS WELTER ${ }^{\mathrm{i}}$
}

Resumo: Este artigo parte das teorizações de Jameson (2011) acerca das variantes de representação da guerra na literatura para investigar a graphic novel de Joe Sacco Notas sobre Gaza (2010). Para a referida análise são mobilizadas categorias como vivência e experiência, a partir dos escritos de Benjamin (1933; 1936), trauma, a partir do clássico texto de Freud (1920), e o testemunho, a partir da elaboração de Seligmann-Silva (1998). Assim, será possível verificar como o trauma conduz a narrativa e problematiza o próprio rememorar, já que a exposição ao traumático é cotidiana. Sacco acaba por compor um novo modo de narrar o inenarrável, o trauma da guerra, com um texto que se constrói pela palavra e pela imagem, funcionando assim o seu narrador como aquele capaz de recolher os destroços daquele mundo em ruínas (Benjamin, 1940).

Palavras-chave: guerra; graphic novel; trauma; Gaza; testemunho.

\begin{abstract}
This paper starts from Jameson's theories about the variants in the representation of war in literature to investigate Joe Sacco's graphic novel, Notas Sobre Gaza (Footnotes in Gaza, 2010). To this analysis it is mobilized the following categories: existence and experience, both connected to Benjamin's writings $(1933 ; 1936)$, trauma, as regarded by Freud (1920) and testimonial, as based on the elaboration of Seligmann-Silva (1998). Therefore, it's possible to see how trauma conducts the narrative and creates question to the act of remembering itself, since the exposition of traumatic events are put in an everyday basis. Sacco ends up composing a new way to describe the indescribable, the war trauma, using a text that build itself by the word and by the image, creating a narrator that is able to collect the wreckages of that ruined world (Benjamin, 1940).
\end{abstract}

Keywords: war; graphic novel; trauma; Gaza; testimonial.

A história é tão leve quanto a vida do indivíduo, insustentavelmente leve, leve como uma pluma, como uma poeira que voa, como uma coisa que vai desaparecer amanhã.

Milan Kundera

\section{Joe Sacco e a reinvenção da guerra enquanto gênero literário}

Sendo o momento histórico elemento formador na arte, a guerra, evento recorrente na história da humanidade, foi e ainda é temática frequente em representações artísticas, formando assim o que Theodor Adorno, em Teoria Estética, chama de "historiografia inconsciente". Aceitando essa máxima do crítico alemão, podemos traçar boa parte da história da civilização ocidental, atendo-nos apenas às representações da guerra na literatura, começando com A Ilíada, de Homero, obra produzida possivelmente no século VIII a. C. tendo como tema a guerra de Troia, que teria acontecido no século XII a. C. 
Podemos subdividir suas representações em gêneros, como a poesia, o teatro, o romance, chegando até a graphic novel. Esses gêneros abarcam tanto a literatura dita erudita, como a poesia épica grega, quanto a literatura fantástica de entretenimento, como o exemplo recente de As crônicas de gelo e fogo, de George R. R. Martin.

Temos, no espaço cronológico entre as duas narrativas citadas, cerca de 3200 anos de histórias bélicas representadas e exploradas ao longo do tempo. Com conflitos e épocas diferentes, a pergunta é: poderíamos falar em um padrão na ficcionalização da guerra? Podemos arriscar que sim, principalmente após a leitura do texto War and Representation (2011), de Fredric Jameson.

Em seu texto, o crítico cita oito variantes de representação da guerra, como "a experiência existencial", atrelada a um ritual de passagem enfrentado por determinado personagem durante o desenrolar da trama; e como "a experiência coletiva", ou seja, a reação de um grupo diante dessa vivência. Essas experiências são facilmente encontradas nas narrativas de guerra, estando ligadas muitas vezes ao trauma e à dor daqueles que direta ou indiretamente participam do conflito. Entre as outras variantes mencionadas, temos "Líderes, oficiais e o exército", comuns na crônica histórica e em textos de heroicização; a "tecnologia", referindo-se às armas utilizadas em batalha, exemplificada tanto com uma AK-47 quanto com o cavalo de Troia; a "representação da paisagem inimiga", muitas vezes fator de dificuldades na luta; a "apresentação das atrocidades", podendo ser uma forma tanto de glorificar um combatente quanto de denunciar barbáries; o "ataque à pátria", como no caso de regiões invadidas e, muitas vezes, devastadas; e a "ocupação estrangeira", irmã do item anterior, com o diferencial da intervenção constante e cerceadora.

Aquém das variantes listadas por Jameson (2009), podemos pensar em outras formas que se repetem nessas construções narrativas, como a representação da guerra real, caso de romances, por exemplo, sobre a Primeira Guerra Mundial, vide Adeus às armas (1929), de Ernest Hemingway, ou a representação da guerra imaginária, exemplificado em Senhor dos Anéis (1954/55), de J. R. R. Tolkien. Importante frisar que as guerras imaginárias têm como ponto forte o fantástico: mundos fantasiosos habitados por criaturas não humanas, mas com elementos do conflito retirados das guerras reais, como no caso de Tolkien e a sua experiência com a Primeira Guerra Mundial. Também podemos pensar nessas narrativas como a história do vencedor e do vencido. Ao tematizar a história do vencedor, a história tende a criação de um herói, como nas menções à Revolução Farroupilha em O tempo e o vento (1949-62), de Erico Verissimo; ao tematizar a história do vencido, deparamo-nos com os aprendizados da derrota ou a denúncia da catástrofe, como em Os persas (472 a.C.), de Ésquilo, e em Os sertões (1902), de Euclides da Cunha.

Ao pensar em vencedores e vencidos, chegamos à dicotomia herói/vilão, comum na literatura fantástica de entretenimento e nos registros mais antigos, como nos poemas épicos, nos quais muitas vezes há uma ode a determinado personagem mostrado como valente em contraponto a outro, covarde, como se pode pontuar em O Uraguai (1769), de Basílio de Gama, com a heroicização dos portugueses/espanhóis e indígenas em comparação à covardia dos jesuítas.

Uma última variante a ser definida, por ora, seria a participação ou não dos escritores no campo de batalha, o que diferenciaria a legitimação de suas narrativas. Podemos citar aqui Nada de novo no front, de Erich Maria Remarque, e Em busca do tempo 
perdido, de Marcel Proust. O primeiro foi soldado na Primeira Guerra Mundial, reconhecido como um escritor pacifista após sua experiência nos campos de batalha. $\mathrm{O}$ segundo viveu a experiência fora do front, ao receber as notícias da guerra que acontecia. Além desses dois exemplos, há uma terceira possibilidade: aqueles que não participaram da batalha e não a vivenciaram, a não ser pela voz do outro, caso de Os varões assinalados: $o$ grande romance da guerra dos Farrapos, de Tabajara Ruas, com as menções à Revolução Farroupilha.

Em meio a tantas possibilidades de representação e problemáticas discutidas em narrativas sobre a guerra, as que mais interessam para o assunto aqui debatido são a vivência e o trauma consequente da exposição a essa violência. Em Além do princípio do prazer (1920), Sigmund Freud reflete sobre a 'neurose traumática', decorrente, em alguns casos, da grande guerra (nesse caso referindo-se à Primeira Guerra Mundial), sendo o trauma entendido como o rompimento de um 'escudo protetor' que acabaria por levar o organismo a atitudes de defesas. Esses soldados, sobreviventes da grande catástrofe, relembrariam seus traumas na compulsão à repetição, através de sonhos ou de comportamentos automáticos.

Às observações do autor somam-se os conhecidos textos de Walter Benjamin: Experiência e Pobreza (1933) e O narrador (1936). Traumatizados pela guerra, desmoralizados pela experiência ${ }^{1}$ de violência ao outro e a si próprio, os soldados voltam silenciosos da frente de batalha. Esse comportamento, somado à neurose traumática analisada por Freud, trará consequências para a arte de narrar, que segundo Benjamin nada mais é do que saber dar conselhos calcados na experiência coletiva e, portanto, na sabedoria, qualidades que não seriam mais encontradas no narrador pós-guerra.

Abalados e vazios de experiência, os soldados retornam da guerra sem conseguir narrar o inenarrável de sua vivência, já que brutalizados pela violência. Freud e Benjamin escrevem seus artigos após a Primeira Guerra Mundial, conflito que acabou com os sonhos de uma geração. Apesar de a produção literária pós-guerra ter sido vasta, as máximas dos dois pensadores parecem se concretizar. Ao pensar na forma escolhida para as produções literárias sobre a guerra, deparamo-nos com o romance, uma experiência individual que tem um fim em si mesmo. Não falamos em transmissão de experiência, de conselhos, portanto de sabedoria, e sim em um relato individual, fruto de um grande trauma, que leva a humanidade a construir novo significado para as palavras e para a sua forma. Podemos pensar, de acordo com essas condições, que novas formas de narrar se engendram a partir desses processos de esvaziamento e preenchimento da narrativa, pois quem vai à guerra não consegue narrá-la (na forma benjaminiana), mas quem não está lá não teria legitimidade para fazê-lo.

Dito isso, podemos pensar não só em novos narradores, como professava Benjamin, mas também podemos rever o suporte capaz de contar essa história hoje, neste caso concretizado na graphic novel. Somando palavras e imagens, a antiga história em quadrinhos demonstra ter as características do gênero textual acrescidas das técnicas cinematográficas de sobreposições de imagens. Se as formas de guerra e suas coberturas

\footnotetext{
${ }^{1}$ A noção de experiência será usada ao longo do texto de duas maneiras: como conhecimento de algo através da prática ou observação, e no sentido benjaminiano de experiência coletiva e sabedoria. Quando necessário, distinguirei o uso.
} 
jornalísticas se modernizaram (hoje podemos saber em tempo real o que se passa na Líbia neste momento, por exemplo), as formas de narrá-las também.

A mais famosa graphic novel sobre o tema, e que claramente inspirou as que viriam no futuro, é Maus (1986), de Art Spielgeman. Ao retratar a história de sua família, judeus fugitivos na Alemanha nazista, com desenhos metafóricos sobre os grupos étnicos (alemães como gatos, judeus como ratos), Spielgeman procedeu a uma inovação nunca antes vista no campo da literatura sobre o Holocausto, e a sua qualidade foi reconhecida e agraciada com um Pullitzer especial - já que a obra não se encaixaria como ficção e nem como biografia em 1992. Seguindo a trilha de Spielgeman, mas traçando o que para alguns críticos é o novo jornalismo, Joe Sacco, jornalista e quadrinista, viveu dois anos entre Israel e Palestina nos anos 1990 e a partir de então passou a desenvolver seu trabalho de jornalista a partir da graphic novel, relatando os conflitos bélicos que vivenciava, aliando sua vivência nessas zonas aos depoimentos coletados. Publicou, nessa linha de trabalho, Palestina - Na faixa de Gaza, Palestina - Uma nação ocupada e Notas sobre Gaza sobre o conflito IsraelPalestina, e também Gorazde - Área de Segurança - A guerra na Bósnia Oriental 19921995 e Uma história em Sarajevo, sobre os conflitos nos Bálcãs com a desintegração da exIugoslávia.

As discussões sobre a validade da graphic novel enquanto gênero literário ou sobre o questionamento do que é real ou ficção não serão apresentadas aqui, visto a qualidade técnica do trabalho desenvolvido por Sacco e o intuito de não limitar a narrativa examinada. A problematização se centrará na representação da guerra atrelada às novas formas de artes (a graphic novel) e às velhas problemáticas de conflitos: o trauma, o testemunho e o esquecimento.

\section{Cotidiano traumático na Faixa de Gaza}

Com uma imagem de dor na primeira página e de uma festa na segunda, Sacco inicia a sua narrativa sobre Gaza. Seu foco são dois incidentes de 1956, em Khan Younis e Rafah, cidades palestinas. Já no prefácio, o autor justifica sua escolha temática e sua construção através de relatos e documentos, da ONU e de Israel, problematizando o relato oral e demonstrando que, em se tratando desses dois eventos, somente esse tipo de narração pode tornar os acontecimentos parte da história, visto que foram "esquecidos" dos documentos oficiais. Esse trabalho de "esquecimento" é demonstrando no posfácio, onde temos acesso a alguns documentos pesquisados pelo quadrinista que ajudaram a formar a história lida. Justificadas e reiteradas suas escolhas, a graphic novel mostra através da imagem e da palavra o problema da continuidade dos episódios em Gaza, um ano atrás, dois anos atrás, cinquenta anos atrás: "Eles poderiam usar a mesma matéria do mês passado - ou até do ano passado - e quem perceberia?" (SACCO, 2010, p. 5)².

Falar do conflito Israel - Palestina mostra-se para nós ocidentais muitas vezes um desafio, mas a narrativa de Notas, que pode ser interpretada como pró-Palestina, tenta, através dos relatos de palestinos e da vivência do jornalista na região, esclarecer o que foi esquecido pela história oficial e que pode ajudar a explicar a história atual. Com um ritmo narrativo em sua maior parte frenético nas suas 389 páginas, a graphic novel sobrepõe

\footnotetext{
${ }^{2}$ Todas as referências a Notas sobre Gaza são da edição: SACCO, Joe. Notas sobre Gaza. São Paulo: Companhia das Letras, 2010. Acrescentarei somente o número da página nas citações subsequentes.
} 
relatos e relatantes, trazendo ao leitor imagens impactantes que às vezes têm a dimensão de uma página inteira. A tragédia cotidiana fica claramente definida através dos depoimentos e das expressões dos personagens, tanto naqueles que narram o passado, quanto naqueles que não veem um futuro.

Discorrer sobre esse conflito não é o objetivo deste trabalho, visto a complexidade do embate e os limites do artigo. Para o que interessa, a formação do estado de Israel responde as perguntas mais importantes sobre os eventos e tópicos aqui tratados. Independente em 14 de maio de 1948, o novo estado de Israel foi atacado naquela mesma noite pelos árabes. Nesse ataque, duzentos mil palestinos foram expulsos para a Faixa de Gaza, destituídos de suas casas e mantimentos, chegando a uma região desértica sem água, comida, habitação ou qualquer condição de higiene. Foram, aos poucos, fazendo desse lugar o que a Faixa de Gaza é hoje: um aglomerado de casas - que crescem para cima, devido à falta de espaço - com $70 \%$ da população vivendo abaixo da linha da pobreza (p. 18). Quando foram removidos para lá, os palestinos moraram embaixo de árvores, em buracos na terra, em tendas, em casas de barro; somente na década de 1950 os tijolos foram enviados.

Os refugiados eram pessoas sem lar, sem meios de sobrevivência e famintas; dependiam de doações sempre escassas; os homens estavam desempregados, ociosos.

Enquanto isso, nos campos que haviam deixado para trás, suas plantações davam frutos. Nas despensas das casas de onde tinham fugido havia azeite e farinha. Tentadoramente, tudo isso estava a apenas algumas poucas horas de caminhada. Tudo isso agora estava nas mãos de um novo povo, os israelenses (p. 36).

Em meio a isto, atentados, assassinatos, incursões e bombardeios. Khan Younis e Rafah têm, no momento em que as histórias são construídas, a maior concentração populacional ao sul de Gaza, vivendo em situação de extrema pobreza. São os netos e bisnetos dos refugiados que chegaram sem nada em 1948 e que continuam, em certa medida, na mesma situação: brutalizados pela miséria, sem condições de higiene e conforto, sem emprego e ameaçados pela violência.

Se hoje, pelo menos, as casas são de tijolos, elas também são alvo dos soldados israelenses: "eles estão destruindo a casa de alguém, as recordações de alguém, a vida de alguém!” (p. 165), esbraveja uma palestina. Com a justificativa de que as casas não são habitadas e servem como esconderijo de armas, ou ponto de encontro de líderes rebeldes, os soldados são instruídos a destruir algumas dessas moradias, mas Sacco parece cuidadosamente mostrar que as suspeitas israelenses não se comprovam ao longo da narrativa.

Os dramas atuais da Palestina não são o foco da pesquisa do jornalista, mas a tragédia do presente se impõe, corroborando com a continuidade dos eventos em Gaza (p. IX). Sem dinheiro e sem ter para onde ir, os desabrigados vão e voltam de suas casas, ou dos espaços onde antes elas existiam. Frases de palestinos como "passo o tempo aqui para poder respirar" (p. 257) ou "só vou até lá para ver como está aquilo que eu sonhei uma vida inteira” (p. 251), demonstram uma terrível condição: sem um novo lar, sem dinheiro e sem entender a barbárie a sua volta. A incompreensão perante essa violação é ilustrada por Sacco, referindo-se a um dos desabrigados: "Para os fotógrafos, a casa dele é uma imagem. 
Para os militantes, uma posição segura. Para os internacionais, uma causa. Para o operador do trator, o trabalho do dia. Mas e para ele?” (p. 191).

Os relatos dos que presenciam essas cenas são perturbadores, principalmente na voz das mães das crianças que nasceram e cresceram em meio ao conflito, e que agora "fica [a criança] rastejando pela casa quando os barulhos começam" (p. 164) e "se mijando todas!" (p. 165). O ódio, que parece ter se iniciado em 1948, quando "eles [os israelenses] semearam o ódio no nosso coração" (p. VII), se intensifica naqueles que não viveram aqueles dias: "Um filho meu tem estilhaços na cabeça e na nuca. Ele está lá, agora mesmo Ou seja, atirando pedras no trator. O sangue da intifada ${ }^{3}$ corre nesses meninos!"” (p. 165). E é reiterado por aqueles que veem a resistência como única alternativa: "Vamos ensinar às crianças que esta é a nossa terra, e que eles são o inimigo!” (p. 167). Ou ainda:

Nossas crianças não têm leite nem comida, e agora estão demolindo as nossas casas! Eles não são humanos, são animais! Hitler não fez isso com eles! Hitler não os expulsou da terra deles! Hitler não demoliu as casas deles! Eu peço a Deus que transforme as crianças israelenses e americanas na mesma coisa que as nossas - órfãs! (p. 188).

Junto à destruição e à pobreza palestina, o jornalista investiga os dois incidentes de $1956^{4}$ que resultaram na morte de centenas de palestinos em seu próprio território. Em 29 de outubro daquele ano, Israel atacou o Egito e invadiu Gaza quatro dias depois. Nesse dia, os militares israelenses em Khan Younis mataram centenas de homens palestinos. Alguns dias depois, em Rafah, os homens foram convocados a comparecer à escola (dia que ficou conhecido como "O dia da escola"), o que acarretou a morte de mais uma centena de homens palestinos. Divergindo sobre as informações, os documentos históricos parecem ter apagado o que verdadeiramente aconteceu nesses dois eventos, e a memória dos que ainda estão vivos mostra-se como a única oportunidade de desvendar esses acontecimentos.

Essa violência latente e alarmante se mostrará em Gaza sob diversos nomes. Pelo dos israelenses:

A artilharia pesada dos morteiros israelenses caiu "ao longo de toda a rua principal" da Cidade de Gaza "no horário de maior movimento", narra o relatório de Bayard, segundo o qual os israelenses usaram "o velho truque de disparar uma ou duas cargas e depois esperar vários minutos para que uma aglomeração se forme e então retomar o alvo original [...] Para causar muitas baixas" (p. 72).

Pelo nome dos americanos: "aqui você pode perder a vida com uma bala fabricada nos EUA enquanto recebe salário dos EUA", pois "eles querem que o povo palestino se concentre na democratização e se esqueça que ainda somos escravos" (p. 34); pelo nome dos outros estrangeiros: "o mundo inteiro nos vê como terroristas. As pessoas que estão nas casas que são demolidas, elas é que são consideradas terroristas" (p. 250).

\footnotetext{
${ }^{3}$ Termo utilizado para designar uma revolta contra um regime opressor, refere-se especialmente aos levantes palestinos contra a ocupação israelense.

${ }^{4}$ Em 1956 houve "a Crise do Canal de Suez, quando as forças militares israelenses promoveram uma breve ocupação à Faixa de Gaza, então controlada pelo Egito" (p. VII).
} 
Mas não só do outro - do "não-palestino" - a violência emana. Através dos relatos sobre os grandes líderes árabes, que governam em interesse próprio, colocando "os interesses pessoais acima da causa nacional" (p. 15), podemos perceber que a violência é também interna, entre aqueles que deveriam ser iguais. O que também é identificado na Sulta, por exemplo, que deveria ser a polícia palestina, mas vive entre a ocupação e a resistência; e também nos próprios rebeldes, que divergem quanto a posturas a serem adotadas, como nos atentados a civis.

Oprimidos pela vivência cotidiana, o trauma do presente e do passado será revelado na busca de informações pelos incidentes de 1956, tanto através dos relatantes quanto através dos guias do jornalista em Gaza. Abed, guia em Khan Younis, considerado um patriota por ter levado um tiro na perna na adolescência ao atirar uma pedra em um soldado israelense, mostra-se tranquilo em boa parte do tempo, mas, por vezes, se torna mais introspectivo, precisando beber alguma coisa "para esquecer de tudo" (p. 17). Segundo ele, "vai demorar uns dez anos para eu superar isto" 5 (p. 331). Khaled, "o procurado", vive foragido desde a primeira intifada (1987), fugiu da Palestina, foi preso e torturado pelos egípcios, mas retornou para casa. Vive em estado de alerta: "faz dois anos que não durmo direito" (p. 56), fugindo, mas de certa forma aguardando a morte, "cansado de lutar, cansado de fugir, cansado da vida limitada que passou a viver" (p. 177); sabe que será assassinado, mas segundo ele "já está demorando demais" (p. 178).

O vermelho do cansaço dos olhos de Khaled será visto em quase todos os militantes jovens, assim como o medo poderá ser visto nos olhos dos que relatam sobre 1956. O "velho fedayee", por exemplo, que mantém a mesma expressão do jovem rebelde, só que agora desgastada pelo tempo, viveu os incidentes e tenta de todas as maneiras escapar daquelas narrativas, pois aqueles acontecimentos estão atrelados a traições políticas e fracassos.

Na tentativa de reconstruir aquele passado - "Ele está nos fazendo lembrar de muitas coisas ruins" (p. 249) -, Sacco coloca seus informantes frente aos fatos novamente: "Quase cinquenta anos depois, Faris ainda é capaz de reconstituir seus passos até as ruínas do castelo do século XIV, que hoje formam um dos lados da praça principal da cidade" (p. 99), sentindo-se "como se fosse uma criança de novo" (p. 101), relata.

Mesmo divergindo nas memórias, as lembranças convergem no trauma vivido. Um desses casos é bastante intrigante. Khamis, um dos sobreviventes do massacre, alega ter estado em casa na morte do irmão, mas as outras testemunhas dizem o contrário. No caso de Khamis, existem algumas possibilidades que explicariam a divergência: os relatos da morte do irmão já foram ouvidos tantas vezes que já fazem parte da sua própria memória; ele estava realmente lá, e as outras testemunhas não se lembram de sua presença devido ao trauma; ou a culpa da sobrevivência fez com que sua memória fosse alterada, afinal, os vivos contrariam a lógica da guerra. Culpa que ficará clara também no relato de Abdull ElHorani, um sobrevivente que conseguiu fugir "por acaso!" (p. 105): era o último da fila. Além da culpa, a resignação e a religiosidade são pressentidas em alguns relatos: "Deus quis que isso acontecesse conosco - que perdêssemos a nossa terra e viéssemos até aqui para sermos assassinados" (p. 111).

\footnotetext{
${ }^{5}$ Abed foi uma das vítimas da operação da destruição das casas palestinas.
} 
Em Rafah, já sabendo que em Khan Younis "os judeus invadiram a cidade, mandaram os jovens saírem de casa, os puseram em fila e abriram fogo" (p. 171), a cidade estava com medo e aterrorizada. Diferentemente do evento na cidade vizinha, esse demorará um dia inteiro, com violações e assassinatos: os homens são convocados à escola, e, desde esse momento, a violência se instala na cidade. Mesmo no caminho, algumas pessoas são assassinadas, como relembra um sobrevivente: "Havia muitos soldados. Alguns em pé e outros deitados, com metralhadoras, atirando nos grupos que passavam diante deles" (p. 213). Outro dirá que, ao chegarem ao muro da escola, "os judeus nos mandaram parar diante do muro e atiraram", "alguns caíram, outros sobreviveram" (p. 226). Enquanto se aproximavam do portão da escola, "os soldados com seus cassetetes" (p. 234) os esperavam. No pátio da escola, mais um palestino relembra que "parecíamos uma plantação de melancia" (p. 265), "mijando um em cima do outro" (p. 267), durante as dez horas em que era feita a triagem em busca de líderes rebeldes. Apesar das memórias serem díspares em certos momentos, a pior lembrança, às vezes não dita, mas vista na expressão daqueles sobreviventes, é o medo.

Os traumas a que essas pessoas foram expostas ao longo dos últimos 50 anos não podem ser vistos isoladamente, já que a exposição a eles não é individualizada. Se a neurose traumática de guerra, segundo Freud, provoca um debilitamento e uma perturbação das capacidades mentais, como reagem essas pessoas que estão diariamente no front? Que reação esperar de quem vê a morte e está de luto com uma frequência rotineira? No luto, o mundo se torna pobre e vazio, até que o ego consiga resolver a sua perda; mas, e se as perdas são diárias? Como o luto se apresenta? A transformação de mortos em mártires é uma das respostas possíveis, pois parece amenizar o sofrimento para transformá-lo em orgulho de uma resistência, mesmo que a morte seja de um menino, morto por atirar pedras nos soldados israelenses.

Sob as mais diversas formas, esse choque emocional aparece no dia a dia palestino, e não se limita ao trauma físico, e sim se expande para a violência psicológica de ser expulso da própria casa (em 1948 e nos 2000) ou de conviver com os fracassos da resistência no passado e no presente. $\mathrm{O}$ permanente estado de tensão, somado ao medo e à resistência como única maneira de lutar, forma, nos relatos de muitos palestinos, uma colcha de retalhos de depoimentos que converge para um quadro único, ainda que configurado como um mosaico: a mesma história é contada tantas vezes, que as pessoas dão uma unidade a ela, se é artificial ou não, não podemos provar. Mas ao contrário de Khamis, que vê o irmão morrer, a memória coletiva é ainda maior, pois o que a memória individual não lembra, a coletiva reconstrói.

\section{Em forma de mosaico: o árduo caminho do narrador}

Tendo como pergunta-problema o questionamento sobre se a lembrança dos sobreviventes será similar diante das narrativas sobre os acontecimentos, Sacco organiza um mosaico de depoimentos, montando aquilo que para ele é a narrativa mais legítima sobre os eventos em Gaza. Os problemas que ele enfrenta quanto à veracidade dos relatos são expostos desde o prefácio. Para o autor, lidar com o testemunho, ou seja, com a ação de presenciar um fato que necessariamente precisa ser validado, gera um problema diante da onipresença do trauma em cada depoimento coletado. Segundo Seligmann-Silva (1998, p. $10)$ 
O testemunho escrito ou falado, sobretudo quando se trata do testemunho de uma cena violenta, de um acidente ou de uma guerra, nunca deve ser compreendido como uma descrição "realista" do ocorrido. De resto, testemunha-se - sempre, diria Walter Benjamin - uma cena traumática. A impossibilidade de uma tradução total da cena vivenciada é um dado a priori.

Soma-se a essa problemática a vivência não isolada e sim cotidiana da zona de conflito que, aceitando a máxima de Benjamin, levaria ao silenciamento dos participantes. Mas, em Notas, temos um palco diferenciado, não falamos de fronts de batalhas, mas de cidades que levam uma vida dentro da normalidade permitida; falamos de outros personagens além dos soldados e combatentes: são mulheres, crianças, idosos, estrangeiros. Segundo Abu Mohammed, professor de árabe, "as ditaduras e o desemprego forçam os árabes a se preocupar mais com o estômago do que com a cabeça" (p. 148). Logo, a sabedoria da experiência, transmitida de geração a geração, não encontraria espaço frente ao cotidiano traumático palestino.

Se analisarmos a situação da região e os conflitos constantes à luz da produção artística, poderemos perceber a sua falta de representatividade no campo literário, não porque os árabes estejam "mais" preocupados "com o estômago", mas porque a violência constante parece não permitir uma reflexão e uma produção artística que venha a ser a "historiografia inconsciente". Talvez, no futuro, seja necessário que a produção literária dessas zonas de conflitos se (re)invente na forma e no conteúdo para poder trazer à arte todo o caos de sua história bélica.

Dito isso, podemos pensar na interpretação dada por Sacco aos testemunhos na sua construção narrativa. Antes de pensar nas memórias conflitantes sobre os eventos, é importante chamar a atenção para a dificuldade de obter esse testemunho, visto que, segundo os palestinos, isso exige um relato sobre a construção de Israel, como é trazida no seguinte depoimento ao autor: "Se você [Sacco] quer escrever um livro que explique mesmo a nossa situação, precisa começar falando do Congresso Sionista da Basileia" ${ }^{6}$ (p. 20). Além disso, sendo estrangeiro, não haveria uma dificuldade no entendimento desses testemunhos? Aos olhos dos palestinos, sim, como salienta um deles: "E para que isso vai servir? Ele é um estrangeiro. Não sabe nada sobre a Palestina" (p. 194).

Isso explica em parte por que a busca do jornalista pelas informações é vista quase como infundada pelos moradores locais. Para eles, "é difícil lembrar de 56, por causa das coisas que acontecem hoje. Por quê? Porque os eventos são contínuos, é uma coisa atrás da outra" (p. 252). Os relatos falam de 1948, de 1967, da história recente, mas parecem se esquecer de 1956, não porque o incidente não seja importante, mas, segundo um palestino, porque "aqui todo dia é 56!" (p. 253). Como preocupar-se com uma história de cinquenta anos atrás enquanto histórias tão horríveis quanto aquela estão acontecendo no momento em que a narrativa se constrói?

Após vencer algumas resistências, Sacco consegue inúmeros depoimentos, muitos deles desencontrados. Ainda que essas pessoas tenham vivido um mesmo momento traumático, o choque a que elas foram submetidas atingiu-as de maneiras diferentes. Falamos aqui de uma violência que foge aos padrões de humanidade a que estamos

\footnotetext{
${ }^{6}$ Congresso sionista realizado pela primeira vez em 1897.
} 
acostumados, sendo fundamental atentar para o fato de que, no caso dos testemunhos masculinos, estamos lidando com um sobrevivente, aquele que contrariou a lógica do evento e precisa lidar com a culpa de ainda estar vivo; no caso dos depoimentos femininos, ouvimos mães e esposas que perderam seus entes queridos.

Assim, a memória individual, fruto de diversas formas de lembrar a experiência, revela-se como algo que justificaria as disparidades nas lembranças, tornando "os contornos difusos; ela [a memória] adiciona e subtrai" (p. 112). Somados a isso, a memória coletiva age, muitas vezes, no sentido de tornar um discurso coeso e legitimá-lo, assim como pode agir como um amálgama, preenchendo os vazios da memória individual, o que acaba por gerar discrepâncias nas lembranças sobre o mesmo acontecimento.

Entre as diferenças de depoimentos temos o caso emblemático de Khamis, citado anteriormente, que lembra estar presente na morte do irmão, mas todos negam a sua presença. Como o próprio Sacco explica:

Não sou capaz de descrever o sentimento arrebatador de culpa e tristeza que toma conta de uma pessoa que sobrevive a uma tragédia em que muitas outras morreram; nem sou capaz de explicar o que poderia levar um indivíduo tão traumatizado a se lembrar da morte do irmão se ele não estava lá - se é que não estava mesmo (p. 116).

Outro episódio divergente refere-se às idades dos palestinos, em Rafah, que foram convocados a ir para a escola. Alguns depoimentos relatam que "os judeus disseram que todos os homens entre quinze e sessenta anos deveriam ir até a escola" (p. 205), ou dos dezesseis aos sessenta, ou dos quinze ao cinquenta etc. Segundo nosso narrador: "quanto mais ouvimos, mais completo fica o nosso retrato sobre aquele dia de 56, e mais céticos nos tornamos quanto àquilo que nos contam" (p. 203). À medida que o mosaico se forma, o próprio narrador percebe o grande problema da sua narrativa: a história que ele montou faz mais sentido que a história contada por todos que a viveram.

A falta de lembrança nos detalhes leva uma das testemunhas a dizer, em tom de justificativa: "você acha que alguém tão assustado consegue ver alguma coisa?" (p. 227). Mas no que se refere ao "dia da escola", uma "parte marcada a fogo até mesmo nas mentes mais debilitadas pela velhice" é o portão da escola: "Embora alguns não se lembrem do arame farpado ou da trincheira, praticamente todos eles se recordam de uma outra coisa que havia na entrada da escola - os soldados com seus grossos cassetetes" (p. 234). Segundo alguns, "parecia o dia do juízo final" (p. 244). Por que essa lembrança seria comum a todos?

Porque em geral isso não é uma coisa que acontece todos os dias. Então uma surra ficaria gravada na sua memória. É por isso que quase todos os homens com quem conversei - até mesmo aqueles que não recordam de quase nada - se lembram das pancadas que levaram no portão da escola... (p. 297).

Através dessa exposição, podemos concluir que "uma surra", ou seja, um ato de violência física, ficaria gravado na memória mesmo anos depois, explicação que não serviria para a violência psicológica, já que os testemunhos só são idênticos nesse caso. Aceitando o argumento, podemos levá-lo adiante alegando que o fato corriqueiro passa despercebido, ao passo que a novidade fica marcada na memória. Assim poder-se-iam explicar as confusões da memória no que se refere à violência psicológica daquele evento: 
ela é cotidiana em Gaza, ao passo que a violência física máxima é a morte. Ilustra a questão a experiência pessoal de Sacco, que se inquieta com "uma saraivada de tiros e ricochetes", "porque não é todo dia que" fica "sob fogo cerrado" (p. 297), enquanto seus amigos palestinos tratam o episódio como rotineiro, sem nenhum tipo de comentário.

Quanto à legitimidade de Sacco como contador daquela história, o que esperar de um narrador que não compartilhou das mesmas experiências sofridas por aqueles a quem ele busca dar voz? E que as estranha enquanto seus depoentes as tratam como naturais? Se o testemunho não é um retrato real da realidade, o quadrinista, como observador da história recente e um não conhecedor da história passada, também pode ser visto como um narrador perplexo e não confiável.

O cotidiano de violência parece não chocar o jornalista até a invasão americana ao Iraque, tendo de conviver com os elogios palestinos a mortes de americanos. Segundo seu amigo palestino, "são soldados, Joe", "vieram para matar". Mas para Sacco, "as imagens dos corpos" o "deixam perturbado" (p. 370). Porém, ao mesmo tempo que ele parece não se chocar anteriormente, não podemos esquecer que o formato da graphic novel leva a essa conclusão, visto que o autor, na maioria das vezes, mantém uma fisionomia impassível diante dos fatos, imagem criada por ele mesmo, que nos guia na narrativa das palavras e das representações imagéticas. Se o nosso narrador se perturba perante os acontecimentos, ou tenta induzir a sua representação como a de uma figura não emotiva, como confiar na sua narrativa sobre a Palestina?

Outros atributos podem colocar em xeque a confiabilidade do recorte de Sacco. Podemos retomar uma das críticas que os próprios palestinos colocavam sobre os seus intentos: ele é um estrangeiro, que direitos teria de narrar essa história? A autorreflexão vem na voz do próprio jornalista: "Afinal de contas, que direito tenho eu de expor o cadáver do menino? Apenas o tempo, o efeito clareador dos anos, tem o poder de despir a morte de seu caráter privado e permitir que ela seja vista de uma forma minimamente digna" (p. 260).

Se ele se propõe a buscar evidências inquestionáveis - "Um jornalista quer fatos, versões definitivas e não um punhado de 'entretantos', 'possivelmentes' ou 'provavelmentes'. E eu prometo extrair nada além de fatos do nosso próximo grupo de testemunhas, não importa o quão frágeis e imperfeitas elas possam ser" (p. 119) -, não tem como garantir a veracidade desses fatos, assim como não tem como atestar quem possui credibilidade e quem não possui (p. 277), o que abrangeria seu próprio relato. Sacco constantemente se mostra ciente da ambiguidade de sua posição, mas isso não interrompe sua construção narrativa. De certa forma, as autorreflexões indicam que todas as dúvidas existentes são a marca de sua própria situação delicada enquanto narrador. Mas se as autoanálises acontecem ao longo do livro, é no final que o autor irá tentar traduzir o sentimento de impossibilidade de narrar o inenarrável, principalmente devido ao relato oral de pessoas que viveram (e ainda vivem) um constante trauma:

Nesse momento eu senti vergonha de mim mesmo, por ter deixado alguma coisa pelo caminho enquanto coletava, desmembrava, dissecava, classificava e registrava informações na minha planilha. E me lembrei das vezes em que sentei diante de senhores que testaram a minha paciência, que divagaram, que misturaram as coisas, que pularam alguns acontecimentos, que não recordavam do arame farpado no portão, ou de quando os mukhtars se levantaram, ou de onde estavam estacionados os jipes, 
me lembrei das vezes em que mentalmente suspirei e revirei os olhos porque sabia mais sobre aquele dia do que eles próprios (p. 385).

\section{Vidas em notas de rodapé}

Relegadas ao pé da página, as notas de rodapé são a parte menos importante de um texto, uma pequena referência, algum comentário mais esclarecedor, nada que não possa ser suprimido ao longo de revisões. Segundo Sacco, os eventos pesquisados por ele em Gaza são notas de rodapé da história, episódios secundários de uma guerra esquecida, pois

A história é capaz de sobreviver sem as notas de rodapé. Elas nem sempre são necessárias, e muitas vezes acabam desviando o foco da narrativa principal. De tempos em tempos, à medida que surgem edições mais abrangentes e atualizadas da história, algumas notas de rodapé são simplesmente descartadas (p. 9).

Não contendo aquilo que pode ser considerado a "história principal", esses pequenos episódios são considerados menos importantes pelo que poderíamos chamar de história oficial; e, à medida que novos incidentes surgem, são relegados ao esquecimento para poder dar espaço a mais uma "história principal", afinal, como lembra o narrador, "a história está sempre em movimento" (p. 9).

Os acontecimentos investigados pelo jornalista não fazem parte dessa história oficial. Em língua inglesa, quase nada fora escrito, os documentos da ONU e de Israel são conflitantes e parecem contar uma outra história; além disso, quando da primeira intenção de relatar o evento de Khan Younis em um artigo de periódico, o texto foi cortado pelos editores da revista. Mas essa é uma visão externa das notas de rodapé, enquanto poderíamos imaginar que, mudando o enfoque, elas não mais seriam recursos tangenciais na história oficial e sim a própria história, como ressalta um depoente: "Aqui todo dia é 56 ! 56 já passou! Aconteceu com o meu avô e a minha avó. Mas este aqui - ele está vivo! E eu estou vivo!" (p. 253).

A argumentação palestina que diminui a importância da pesquisa segue essa linha, a do tratamento do evento como uma nota de rodapé, portanto sem maiores importâncias. Isso pode ser explicado pela exposição à violência igual ou maior do que aquela de Rafah e Khan Younis: por que falar dos mortos, se os vivos estão em convívio diário com a morte? Para os habitantes da Faixa de Gaza, a sucessão de catástrofes tornou esses acontecimentos rotineiros, lá "a tinta nunca seca" (p. 12), eles "nunca se deram ao luxo de digerir uma tragédia antes que outra lhes fosse imposta" (p. IX). A história de assassinatos, atentados e massacres se repete ao longo dos anos, fazendo com que os traumas se sobreponham e sejam soterrados na memória de cada um. Segundo Sacco, por exemplo, “o assassinato de um palestino em Gaza é um episódio costumeiro. Sua perda só causa comoção no círculo mais próximo de familiares, amigos e vizinhos"; é, em suma, uma nota de rodapé. "Já o assassinato de uma norte-americana -" (p. 363), impressionará o mundo.

Para muitos, 1956 já passou, mas para o jornalista "o passado e o presente não podem ser desassociados com tanta facilidade; eles são parte da mesma sucessão implacável de episódios, uma distorção histórica" (p. IX). Acompanhando essa ideia, podemos pensar sobre a repetição e a continuidade dos eventos, pois ao mesmo tempo em que aquele horror já passou, em Gaza todo dia é 1956. Um diálogo entre um jovem palestino e Sacco ilustra a questão: "Esqueça do passado. E quanto a hoje?", no que 
responde o autor: “'Daqui a cinquenta anos', eu digo, 'as pessoas vão se esquecer de você também"” e continua: "Mas é assim que as coisas são: os jovens não querem ouvir falar de $56 "$ (p. 200).

Se um massacre do passado é relegado ao esquecimento, provavelmente os acontecimentos recentes em Gaza também serão, visto que a continuidade da história leva a crer que os eventos, de certa maneira, se repetirão ao longo do tempo. Sendo contínuos, a necessidade de lembrar uma página do passado distante é justificada através das palavras de Sacco, considerando que a rememoração desses fatos "podem ser úteis para entender como e por que - nas palavras de El-Rantisi - o ódio foi 'semeado' no coração dos palestinos" (p. IX).

Aqui, é possível traçar um paralelo com outro texto de Walter Benjamin, Sobre o conceito da história (1940). Em uma de suas teses, Benjamin (1994) utiliza a metáfora do "Anjo da História":

Há um quadro de Klee que chama Angelus Novus. Representa um anjo que parece querer afastar-se de algo que ele encara fixamente. Seus olhos estão escancarados, sua boca dilatada, suas asas abertas. O anjo da história deve ter esse aspecto. Seu rosto está dirigido para o passado. Onde nós vemos uma cadeia de acontecimentos, ele vê uma catástrofe única, que acumula incansavelmente ruína sobre ruína e as dispersa a nossos pés. Ele gostaria de deter-se para acordar os mortos e juntar os fragmentos. Mas uma tempestade sopra do paraíso e prende-se em suas asas com tanta força que ele não pode mais fechá-las. Essa tempestade o impele irresistivelmente para o futuro, ao qual ele vira as costas enquanto o amontoado de ruínas cresce até o céu. Essa tempestade é o que chamamos progresso (BENJAMIN, 1994, p. 226).

O anjo de Benjamin olha para trás e só vê catástrofe (onde nós vemos vários acontecimentos únicos), mas não tem tempo para juntar aqueles pedaços, pois ele é impulsionado para frente por uma tempestade chamada "progresso". A metáfora do anjo questiona esse ideal de não olhar para o passado e apontar para o futuro. Enquanto isso, aqueles fatos, que pensamos estagnados (já que são parte do passado), acabam por ser transformados em um grande amontoado de catástrofes, formando uma única e gigantesca tragédia, que acompanha a história da humanidade por todos os tempos. Assim, o "Anjo" parece corroborar o argumento de Sacco, balizando sua estratégia diante da sucessão de catástrofes: congelar no tempo um único evento, dissecá-lo até a última gota, para que talvez possamos ter alguma resposta frente a catástrofes do presente.

Se Benjamin legitima o argumento do jornalista, é um israelense, o escritor Amós $\mathrm{Oz}$, que pode trazer um contraponto acerca da discussão sobre a continuidade dos fatos. Na voz de Prófi, o narrador de Pantera no Porão:

Certa vez [minha mãe] me contou que quando era uma garotinha de oito anos ficou sentada, certa manhã de verão, na beira de um riacho lá na Ucrânia, perto de um moinho. (...) Ela descreveu a curva onde o rio era engolido pela floresta. Era ali que sempre desapareciam as coisas que o rio carregava em seu dorso: cascas de árvores, folhas caídas. No pátio do moinho ela encontrou uma veneziana quebrada, pintada de azul-claro, e a jogou no riacho. Ela imaginou que esse riacho, que vinha da floresta e nela desaparecia outra vez, devia fazer outras voltas nas profundezas da floresta, meandros e volteios que acabavam fechando um círculo. Assim, ficou ali sentada 
durante duas ou três horas, esperando que sua veneziana completasse o circuito e aparecesse de novo. Porém, só os patinhos voltaram (OZ, 1999, p. 64-65).

Nesse romance, de forte cunho autobiográfico, Oz, intelectual engajado e lúcido sobre o conflito Israel-Palestina, traz a voz de um menino que acompanhou o último ano da ocupação britânica em Israel (1947). Através de uma história contada pela mãe, a metáfora de "veneziana azul" justifica a necessidade da troca de experiências passada de geração a geração:

O dia em que aquele pedaço de madeira por fim voltar ao ponto em que minha mãe o jogou na água, ao lado daquele moinho, ele não será visto pelos nossos olhos, que não mais existirão, e sim por olhos estrangeiros. Os olhos de algum homem ou mulher que não poderá sequer imaginar que aquele objeto flutuando no riacho daqui veio e para cá voltou. Que pena, disse minha mãe: se alguém estiver por lá e vir o meu sinal passar outra vez, flutuando diante do moinho, se alguém chegar a notar, como irá saber que se trata de um sinal, uma prova de que tudo gira em círculos? Na verdade, é possível que essa pessoa que casualmente esteja lá no exato momento em que a veneziana voltar também decida fazer dela um sinal, para testar se existe ou não uma volta. Porém, quando o círculo se fechar outra vez, também essa nova pessoa não mais existirá. Outro estranho estará à beira do riacho, e também ele não terá a menor ideia. Vem daí a necessidade de contar (p. 65-66).

Na metáfora da "veneziana azul", a ideia de continuidade na História é posta em xeque. Mesmo que continue sempre igual, aqueles que veem a veneziana enxergam-na de maneiras diferentes, pois cada uma dessas pessoas foi exposta a experiências díspares. Assim, um evento traumático, por mais que pensamos que ele se repita na história (como a continuidade dos episódios em Gaza), que seja essencialmente igual ao passado, acaba visto como algo pelo qual aqueles que estarão expostos a ele poderão dar outro significado. Por essa lógica, se considerarmos que os eventos em Gaza são contínuos, devemos também considerar que os olhos que os veem não são sempre os mesmos olhos, o que faz com que a investigação ganhe ainda mais legitimidade e o espaço das notas de rodapé se torne cada vez mais central.

Se não há mais como narrar - pois voltamos da guerra vazios de experiências -, o passado, por sua vez, relegado ao total esquecimento, se torna uma única grande tragédia. Contudo, se aceitarmos o vazio e o esquecimento do passado em prol do futuro, o próprio presente poderá se transformar em um grande círculo repetitivo de acontecimentos sem significado, de tragédias e vazios. Por isso, a "veneziana azul" de Oz traz uma nova luz sobre a narrativa: se não contarmos, a história não terá sentido. Se por um lado o narrador busca resgatar o passado, tal como o anjo da história, congelando e dissecando-o, ele enfrenta o problema de estar alheio a esse passado. A tragédia do anjo, em última instância, pode ser vista como a tragédia de Sacco - não há tempo para juntar os destroços, ainda que ele lute para isso.

Por outro lado, a janela de $\mathrm{Oz}$ indica a necessidade de contar para que o sentido do passado não se perca diante de um presente que se inspira somente na noção de progresso. Em alguma medida, buscar o sentido é a tarefa inglória daqueles que precisam narrar até mesmo o inenarrável. Diante desse dilema, Sacco parece resolvê-lo através do texto imagético e escrito. Em alguma medida, seu trabalho enquanto narrador é revelar a 
simbiose entre a impossibilidade de narrar a tragédia ao mesmo tempo em que esse ato é tão necessário para lhe dar sentido.

\section{Considerações finais}

Frequentemente fazendo parte das construções artísticas, a guerra será representada nas mais diversas construções literárias, como afirmado anteriormente. Além disso, abarcará os mais diversos conflitos, nas mais diversas épocas, nos mais diversos gêneros, pensando aqui também na cultura pop, como a literatura de entretenimento e as produções televisivas. Assim, podemos considerar que a guerra pode ser vista, sim, enquanto um gênero literário, que respeita certas convenções, mas que também reinventa sua forma.

Essa reinvenção da forma é exemplificada com a graphic novel de Joe Sacco. Independente de a obra ser avaliada enquanto um novo jornalismo, ela é tratada aqui como uma nova forma de narrar o inenarrável. Através dos relatos de palestinos e do próprio jornalista, (re)conhecemos os conflitos e a realidade de um front com a legitimação do discurso de Sacco através do testemunho.

Aceitando que o testemunho se referirá sempre a uma situação traumática, a construção da narrativa se dará por meio desse trauma, que serve como fio condutor e que, no caso palestino, congrega mais de cinquenta anos de violações e violência, de expulsões e de luto. A continuidade desse ciclo levará ao que poderíamos chamar de soterramento da memória: como posso lembrar o massacre ocorrido em 56 se, agora, minha casa está sendo destruída? Frente a essa realidade, Sacco formará, pelos estilhaços da memória de suas testemunhas, o seu mosaico, coletado e organizado por ele mesmo.

Os problemas do trabalho com o relato oral são colocados desde o prefácio pelo jornalista, já de saída admitindo suas possíveis limitações enquanto narrador daquela história. Ao optar pela forma da graphic novel, Sacco, de certa forma, também encontra uma saída para essas limitações: ela dá conta, em palavras e imagens, dos pequenos e grandes traumas de Gaza. Se as palavras não conseguem dar conta da ambientação do conflito diário, o recurso da imagem ilustra e diz o que a palavra parece não conseguir. Se os soldados voltaram silenciosos da guerra, vazios de experiência, e a forma de narrar precisou se reinventar, talvez, hoje, a imagem associada à palavra consiga responder com objetividade e sensibilidade ao inenarrável dessa violência - vide Maus, de Art Spielgeman e as demais obras de Sacco -, colocando, dessa maneira, a graphic novel como uma das formas capazes de dar conta da narrativa de guerra.

O trabalho com o testemunho leva, em certo momento da narrativa, à problematização do sentido daquela construção, já que Sacco acredita que sua história, a que organizou através dos relatos, faz mais sentido que a das testemunhas, o que nos leva à sua capacidade de reinvenção desses relatos e, de certa forma, à sua ficcionalização. A partir do momento em que o narrador ouve e seleciona os testemunhos, reorganiza a narrativa, olha para o passado e tenta recolher aqueles mortos, age como o "Anjo da História", através da "veneziana azul": ouvindo, como a nova pessoa que ainda não entende aquele significado, mas que a partir daí dará seu próprio veredicto sobre aquele acontecimento, reinventando aquela história e apropriando-se dela. Em outras palavras, a reinvenção não é apenas a ação sobre o passado, mas a produção de um significado ainda maior sobre ele no presente. 
Se a reinvenção parece ser visível na construção da palavra, ela é exposta também na forma, a graphic novel, mas é válido ressaltar que essa refeitura faz parte de um olhar estrangeiro sobre Gaza. A literatura palestina também precisa se (re)inventar no futuro para que possa falar o que viveu, construindo a sua "historiografia inconsciente", através do trabalho intelectual, conseguindo assim olhar para o passado, recolher os escombros e contar para os novos olhos o que é a sua história. Quem sabe, dessa maneira, evitando que a leveza da história somada à tempestade do progresso possa tirar as pequenas histórias do discurso oficial, relegando-as ao espaço do esquecimento das notas de rodapé.

\section{REFERÊNCIAS}

ADORNO, Theodor W. Teoria Estética. Lisboa: Edições 70, 1988.

BENJAMIN, Walter. Magia e técnica, arte e política: ensaios sobre literatura e história da cultura. 7. ed. São Paulo: Brasiliense, 1994.

CORNELSEN, Elcio; BURNS, Tom (Org.). Literatura e guerra. Belo Horizonte: UFMG, 2010.

FREUD, Sigmund. Além do princípio de prazer (1920). In: - Além do princípio do prazer, psicologia de grupos e outros trabalhos. Rio de Janeiro: Imago, 1987.

. Luto e Melancolia (1917[1915]). In: . A história do movimento pscanalítico, artigo sobre metapsicologia e outros trabalhos. Rio de Janeiro: Imago, 1987.

JAMESON, Fredric. War and Representation. PMLA, Outubro 2009. V. 124, N. 5, p. 1532-1547.

OZ, Amos. Pantera no porão. Trad. Isa Mara Lando. São Paulo: Companhia das Letras, 1999.

SACCO, Joe. Notas sobre Gaza. Trad. Alexandre Boide. São Paulo: Companhia das Letras, 2010.

SELIGLMANN-SILVA, Márcio. Literatura de testemunho: os limites entre a construção e a ficção. Revista de Mestrado em Letras UFSM (RS) janeiro/junho/1998.

Recebido em: 15/05/2015

Aceito em: 10/06/2015

\footnotetext{
${ }^{\text {i }}$ Doutora em Literatura Brasileira pela Universidade Federal do Rio Grande do Sul. Professora adjunta do setor de Literatura Brasileira da Universidade Federal do Rio Grande do Norte. Email: julianewelter@gmail.com.
} 